\title{
Population analysis of a chromosome polymorphism in Astyanax (Teleostei, Characiformes) species endemic to the Iguaçu River
}

\author{
Daniel Luis Zanella Kantek ${ }^{1}$, Roger Raupp Cipriano ${ }^{2}$, Rafael Bueno Noleto ${ }^{2}$, \\ Alberto Sergio Fenocchio ${ }^{3}$, Roberto Ferreira Artoni ${ }^{4}$ and Marta Margarete Cestari ${ }^{2}$ \\ ${ }^{1}$ Laboratório de Citogenética, Departamento de Genética e Evolução, \\ Universidade Federal de São Carlos, São Carlos, SP, Brazil. \\ ${ }^{2}$ Laboratório de Citogenética Animal, Universidade Federal do Paraná, Curitiba, PR, Brazil. \\ ${ }^{3}$ Departamento de Genética, Universidad Nacional de Misiones, Misiones, Argentina. \\ ${ }^{4}$ Departamento de Biologia Estrutural, Molecular e Genética, \\ Universidade Estadual de Ponta Grossa, Ponta Grossa, Paraná, Brazil.
}

\begin{abstract}
Chromosomal analyses were performed in the fish Astyanax sp.D collected from three different points: two streams from the right bank and one from the left bank of the Upper Iguaçu River, Paraná State, Brazil. The individuals from all localities possess $2 n=50$ chromosomes and a FN = $84(4 m+24 s m+6 s t+16 a)$. The C-banding pattern was similar in all populations. However, within each population, an interindividual variation concerning the number and localization of heterochromatic bands was observed. Some of these variations were quantified in each population, and the results indicate that the samples were not different when studying the variable frequencies. Considering that Astyanax $\mathrm{sp} . \mathrm{D}$ is typical in the headwaters of the Iguaçu River, these results were not expected. The data indicate that gene flow is occurring and that the Iguaçu River is not an ecological barrier among the Astyanax sp. D populations.
\end{abstract}

Key words: population cytogenetics, chromosome variations, Astyanax fish.

Received: August 21, 2006; Accepted: May 22, 2007.

Taxonomic studies in Astyanax of the Iguaçu River, southern Brazil, show that at least eleven different taxonomic entities may be differentiated in this locality: Astyanax sp. A (currently cited as A. gimnogenis) to Astyanax sp.F (Sampaio, 1988), A. altiparanae (Garutti and Britski, 2000), Astyanax ita (Almiróm et al., 2002), Astyanax leonidas (Azpelicueta et al., 2002), Astyanax totae (Haluch and Abilhoa, 2005) and Astyanax varzeae (Abilhoa and Duboc, 2007). Although lacking a valid scientific name, Astyanax sp. species of the Iguaçu River are considered natural taxonomic entities (Severi and Cordeiro, 1994; Agostinho and Gomes, 1997; Kantek et al., 2003; Vitule and Abilhoa, 2003; Ingenito et al., 2004).

The main habitats of Astyanax sp.D are the headwaters of the Upper Iguaçu River (Sampaio, 1988). Due to the isolation of many populations in streams, caused by the water volume in the inferior region of the basin, the detection of differences among populations caused by distinct selective pressures and also stochastic variations is expected.

Send correspondence to Daniel Luis Zanella Kantek. Departamento de Genética e Evolução, Universidade Federal de São Carlos, Rodovia Washington Luís km 235, 13565-905 São Carlos, SP, Brazil. E-mail: daniel_kantek@ hotmail.com.
According to Buckup (1999), the stream species tend to present larger speciation rates, considering that their more restricted populations may genetically diverge with a faster rate than those typical of large rivers.

Cytotaxonomy is a useful tool for the comparison of populations of the same species. In Astyanax, interpopulational karyotypic differences were detected in many species, including A. scabripinnis (Martins et al., 1984; Moreira-Filho and Bertollo, 1991; Mizoguchi and Martins-Santos, 1998; Maistro et al., 1998), A. fasciatus (Morelli et al., 1983; Centofante et al., 2003), and $A$. altiparanae (Jim and Toledo, 1975; Morelli et al., 1983; Fernandes and Martins-Santos, 2004). Sampaio (1988) and Kantek et al. (2007) consider Astyanax sp.D and A. scabripinnis as very similar species. Thus, bearing in mind the intense interpopulational karyotypic variability reported in the literature for $A$. scabripinnis, it is expected that variations could also occur in the same proportion in $A$. sp.D.

In this context, this work has the objective of verifying a possible populational structure in the samples of Astyanax sp.D from the Iguaçu River through the comparison of karyotypic data. 
One hundred and eighteen Astyanax sp.D specimens were collected in the Upper Iguaçu River basin and were cytogenetically analyzed: 41 (4 males and 37 females; MHNCI - Museu de História Natural Capão da Imbuia 9095) from the Bicudo River (Point 1 - UTM 22J0635133/7171020), 44 (12 males and 32 females; MHNCI 9153) from the Poço Claro River (Point 2 - UTM 22J0635327/7179957), and 33 (12 males and 21 females; MHNCI 9153) from a nameless stream located to the left bank of the Iguaçu River basin (Point 3 - UTM 22J0633551/7166935). The Bicudo and Poço Claro Rivers are on the right bank of the Iguaçu River. Mitotic metaphases were obtained according to the indirect method described by Fenocchio et al. (1991). C-banding was performed according to Sumner (1972). Chromosomes were classified according to Levan et al. (1964).

For population analyses, chromosome variants (inversions) were detected by C-banding. In order to obtain the mean number of inversions per individual in each population, only the chromosomes belonging to pairs 18 and 19 with large interstitial heterochromatic blocks (IB) were considered. A contingency table was constructed to verify whether individual frequencies with zero, one, two, or three IB differ among the Astyanax sp.D samples. The Kolmogorov-Smirnov normality test was used to evaluate the distribution data. A Kruskal-Wallis non-parametric test was performed to compare the mean number of inversions per individual in each population. InStat 3.05 program was used in the analyses.

The three analyzed populations possess a diploid number of 50 chromosomes, made up of 2 metacentric pairs (m), 12 submetacentric pairs (sm), 3 subtelocentric pairs (st), and 8 acrocentric pairs (a), with a $\mathrm{FN}=84$ (Figure 1a, $1 \mathrm{~b}$ and $1 \mathrm{c})$. No sex chromosome dimorphism was detected. The telomeric regions of many sm, st, and a chromosomes were more strongly evidenced by C-banding (Figure 1d). However, interindividual variations occur within each population. By comparing the acrocentric chromosomes of the individuals, it was possible to reveal the variation in the number and localization of heterochromatic blocks (Figure $2 \mathrm{a}, 2 \mathrm{~b}$ and $2 \mathrm{c}$ ). Some chromosomes bearing the IB possess another heterochromatic band located below the IB (for an example, see Figure 2a, individual B, pair 18).

The frequency of specimens with $0,1,2$, or 3 IBs in each sample is shown in Table 1 . The chi-square independence test indicated that at least one of the samples differs from the others in this parameter $(\mathrm{p}=0.0476)$. The $p$-values referring to comparisons between sample pairs are summarized in Table 2.

The IB average values are: Point $1=1.585$ (SE - Standard error of mean $=0,139$; $\mathrm{SD}$ - Standard deviation $=$ 0,894), Point $2=1.523(\mathrm{SE}=0,147 ; \mathrm{SD}=0,976)$, and Point $3=1.242(\mathrm{SE}=0,151 ; \mathrm{SD}=0,867)$. The KolmogorovSmirnov test indicated that the data were not normally distributed $(\mathrm{p}=0.0032$ - Point $1 ; \mathrm{p}=0.0022$ - Point 2;

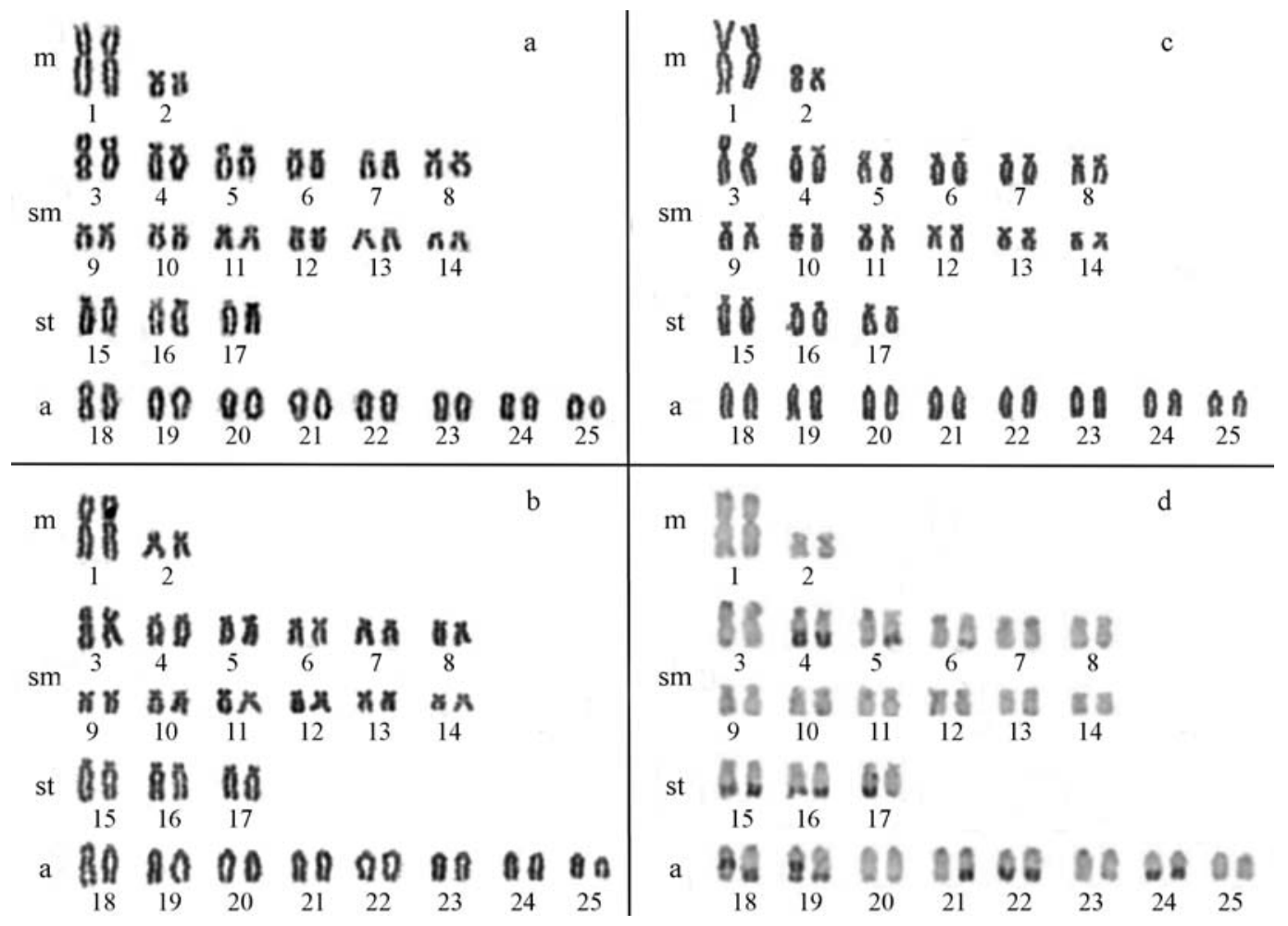

Figure 1 - Karyotypes of Astyanax sp.D. Giemsa staining of specimens collected in the Bicudo (a) and Poço Claro (b) Rivers and in the nameless stream from the left bank of the Iguaçu River basin (c). General C-banding pattern (d). 


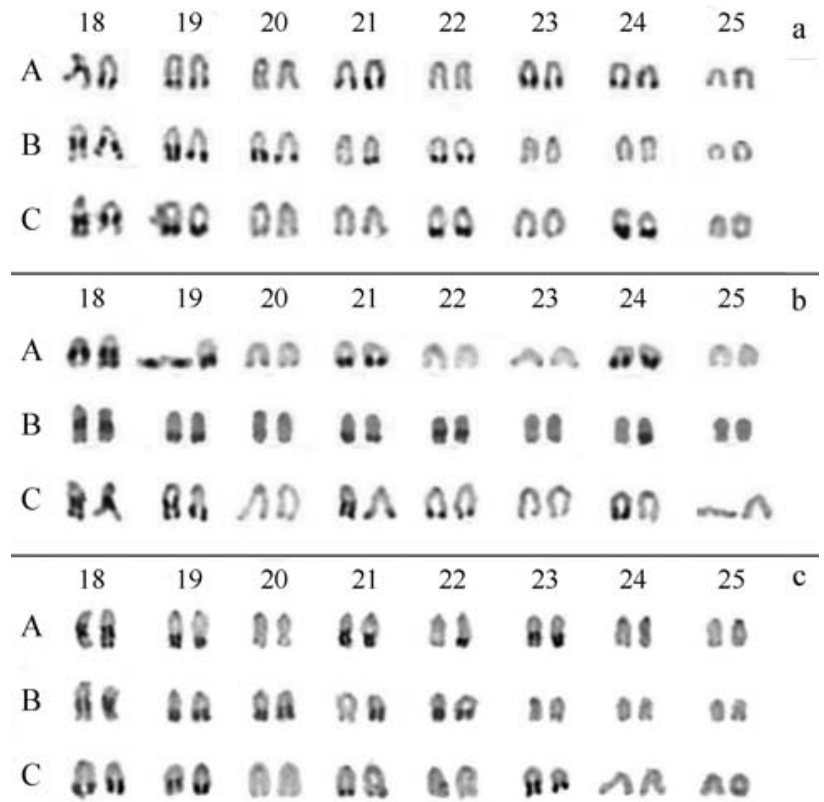

Figure 2 - Interindividual variation of heterochromatic blocks in Astyanax sp.D samples from the Bicudo (a) and Poço Claro (b) Rivers and from the nameless stream (c) from the left bank of the Iguaçu River basin. The letters at left represent some of the analyzed individuals. The numbers show the acrocentric chromosome pairs. Note that individual "B" of Poço Claro has an interstitial band on pair 22 .

$\mathrm{p}=0.0128$ - Point 3 ). According to the Kruskal-Wallis test, the averages do not differ $(p=0.229)$.

The presence of the interstitial bands on pairs 18 and 19 was interpreted by Kantek et al. (2007) as a consequence of possible paracentric inversions in chromosomes bearing telomeric heterochromatic blocks. The occurrence of these alterations in three chromosome pais $(18,19$, and 22) may be the indication of a tendency for the occurrence of similar chromosomal rearrangements (karyotypic ortoselection) in Astyanax sp.D.

If Astyanax sp.D was restricted to the headwaters of the Iguaçu River (Sampaio, 1988), it would be expected for the populations to be isolated in such a way as to prevent, at least partially, the gene flow among them. The present work showed that there are no cytogenetic differences between the populations, and that all variations are intrapopulational. Furthermore, when the present results are compared to those of Kantek et al. (2007), who analyzed an $A$. sp.D sample from a distinct river located in the eastern region of Curitiba (PR), it is seen that the karyotypic pattern is faithfully repeated, including the presence of the interstitial heterochromatic bands and the intrapopulational variation. Thus, these results suggest the existence of gene flow among the populations.

Despite the result of the contingency test, which indicated that the distribution of the IBs is not equal among the three populations, the $p$-value was very close to 0.05 . Thus, it is possible to assume that the three populations are similar. Moreover, when comparing only two populations
Table 1 - Frequency of specimens with $0,1,2$, or 3 interstitial heterochromatic blocks in each sample.

\begin{tabular}{lcrrr}
\hline Number of heterochromatic blocks & 0 & 1 & 2 & 3 \\
\hline Bicudo River & 3 & 19 & 11 & 8 \\
Poço Claro River & 9 & 9 & 20 & 6 \\
Nameless stream & 6 & 16 & 8 & 3 \\
\hline
\end{tabular}

Table 2 - $p$-values of the contingency test between sample pairs. Point 1 Bicudo River, Point 2 - Poço Claro River, Point 3 - nameless stream.

\begin{tabular}{lccc}
\hline & Point 1 & Point 2 & Point 3 \\
\hline Point 1 & - & 0.0247 & 0.3653 \\
Point 2 & - & - & 0.0635 \\
\hline
\end{tabular}

through the contingency test, only the comparison between Point 1 and Point 2 suggests differences. The sample collected in the stream located on the left bank of the Iguaçu River (Point 3) did not differ from the other two samples, suggesting the occurrence of gene flow between the Astyanax sp.D populations. The Kruskal-Wallis test result indicates that the mean number of IBs per individual in each sample does not differ, reaffirming the hypothesis that the samples are elements of a single population. Another evidence in favor of the gene flow hypothesis is that, according to Abilhoa, V. (personal communication), some $A$. sp.D specimens are also sporadically collected in the waters of the Iguaçu River.

Morphological and/or molecular marker analyses should be used in future approaches in order to confirm the equality similarity between the analyzed populations, as proposed in the present work through chromosomal data.

\section{Acknowledgments}

We thank Vinícius Abilhoa from Museu de História Natural Capão da Imbuia (Curitiba-PR) for sample identification. Financial support was provided by CAPES (Coordenação de Aperfeiçoamento de Pessoal de Nível Superior).

\section{References}

Abilhoa V and Duboc LF (2007) A new species of the freshwater fish genus Astyanax (Ostariophysi, Characidae) from the rio Iguaçu basin, southeastern Brazil. Zootaxa 1587:43-52.

Agostinho AA and Gomes LC (1997) Reservatório de Segredo: Bases Ecológicas para o Manejo. EDUEM, Maringá, 387 pp.

Almirón AE, Azpelicueta M de la M and Casciotta J (2002) Astyanax ita sp. n - A new species from de Iguazú basin, in Argentina (Teleostei, Characiformes, Characidae). Zool Abh 52:3-10.

Azpelicueta M de las M, Casciotta JR and Almirón AE (2002) Two new species of Astyanax (Characiformes, Characidae) 
from de Paraná Basin, in Argentina. Rev Suisse Zool 109:243-259.

Buckup PA (1999) Sistemática e biogeografia de peixes de riachos. In: Caramaschi EP, Mazzoni R and Peres-Neto PR (eds) Ecologia de Peixes de Riachos. Série Ecologia. Brasiliensis, Rio de Janeiro, pp 91-138.

Centofante L, Bertollo LAC, Justi AJ and Moreira-Filho O (2003) Correlation of chromosomal and morphologic characters in two Astyanax species (Teleostei, Characidae). Ichthyol Explor Freshwat 14:361-368.

Fenocchio AS, Venere PC, César ACG, Dias AL and Bertollo LAC (1991) Short term culture from solid tissues of fishes. Caryologia 44:161-166.

Fernandes CA and Martins-Santos IC (2004) Cytogenetic studies in two populations of Astyanax altiparanae (Pisces, Characiformes). Hereditas 141:1-5.

Garutti V and Britski HA (2000) Descrição de uma espécie nova de Astyanax (Teleostei, Characidae) da bacia do alto Rio Paraná e considerações gerais sobre as demais espécies do gênero na bacia. Comum Mus Ciênc Tecnol PUCRS Ser Zool 13:65-88.

Haluch CP and Abilhoa V (2005) Astyanax totae, a new species (Teleoistei, Characidae) from the upper rio Iguaçu Basin, southeastern Brazil. Neotrop Ichthy 3:383-388.

Ingenito LFS, Duboc LF and Abilhoa V (2004) Contribuição ao conhecimento da ictiofauna da bacia do alto rio Iguaçu, Paraná, Brasil. Arq Ciênc Vet Zool UNIPAR 7:23-26.

Jim SM and Toledo V (1975) Citogenética de Astyanax fasciatus e Astyanax bimaculatus (Characidae, Tetragonopterinae). Cienc Cult 27:1122-1124.

Kantek DLZ, Fenocchio AS and Cestari MM (2003) Cytogenetic Characterization and NOR Polymorphism in Astyanax sp. C (Tetragonopterinae, Characidae) from First Plateau of Iguaçu River (Paraná State, Brazil). Cytologia 68:19-24.

Kantek DLZ, Noleto RB, Fenocchio AS and Cestari MM (2007) Cytotaxonomy, heterochromatic polymorphism and natural triploidy of a species of Astyanax (Pisces, Characidae) endemic to the Iguaçu River Basin (Paraná, Brasil). Braz Arch Biol Technol 50:67-74.

Levan A, Fregda K and Sandberg AA (1964) Nomenclature for centromeric position on chromosomes. Hereditas 52:210220.

Maistro EL, Oliveira C and Foresti F (1998) Comparative cytogenetic and morphological analysis of Astyanax scabripinnis paranae (Pisces, Characidae, Tetragonopterinae). Genet Mol Biol 21:201-206.

Martins NS, Oliveira MA, Waldrigues A, Giuliano LE and Araújo AMLV (1984) Estudo cariotípico de Astyanax scabripinnis paranae da região de Londrina, PR. Cienc Cult 36:862-863.

Mizoguchi SMHN and Martins-Santos IC (1998) Cytogenetic and morphometric differences in populations of Astyanax. Genet Mol Biol 21:55-61.

Moreira-Filho O and Bertollo LAC (1991) Astyanax scabripinnis (Pisces, Characidae): A species complex. Rev Brasil Genet 14:331-357.

Morelli S, Bertollo LAC, Foresti F, Moreira-Filho O and Toledo-Filho SA (1983) Cytogenetic considerations on the genus Astyanax (Pisces, Characidae). I. Kariotypic variability. Caryologia 36:235-244.

Sampaio FAA (1988) Estudos taxonômicos preliminares dos Characiformes (Teleostei, Ostariophysi) da Bacia do Rio Iguaçu, com comentários sobre o endemismo desta fauna. Master's Thesis, Universidade Federal de São Carlos, São Carlos.

Severi W and Cordeiro AAM (1994) Catálogo de Peixes da Bacia do Rio Iguaçu. IAP/GTZ, Curitiba, 128 pp.

Sumner AT (1972) A simple technique for demonstrating centromeric heterochromatin. Exp Cell Res 74:304-306.

Vitule JRS and Abilhoa V (2003) A composição da ictiofauna na bacia hidrográfica do rio Piraquara, alto rio Iguaçu, Região Metropolitana de Curitiba, Paraná, Brasil. Estudos de Biologia 25:43-49.

Associate Editor: Cláudio Oliveira 